\title{
燃料喷霧が混在する可燃混合気中を伝ぱする火炎の構造*
}

\author{
吉 田整*1，新 井 雅 隆*2 \\ 廣 安 博之*3, 横 谷 昌 道*4
}

\section{Structure of Flames Propagating in Spray Compound Combustible Mixtures}

\author{
Hajime YOSHIDA, Masataka ARAI, \\ Hiroyuki HIROYASU and Masamichi YOKOTANI
}

\begin{abstract}
High speed schlieren movies were taken for detailed observation of the physical structure of flames propagating in propane-air mixtures containing kerosene spray. Effects of an overall equivalence ratio and a mixture ratio of propane/kerosene to the total fuel on the structure were examined. Fractal analysis of the flame structure was also attempted. As a result, two typical flame structures were observed, into which flame structures were classified according to propane concentration. One consisted of droplets ignited successively, the other consisted of flame front propagating in the interdroplet propane-air mixture. In the latter, flame front had fractal character and its fractal dimension increased and decreased with the flame propagation velocity.
\end{abstract}

Key Words: Internal Combustion Engine, Combustion Phenomena, Flame, Gaseous Fuel, Liquid Fuel, Flame Structure, Flame Propagating Velocity, Fractal Analysis, Fractal Dimension

\section{1. ま え がき}

噴霧燃焼は，工業用ボイラや自動車用ディーゼル機 関など広い分野で従来から利用されている。近年，そ の優れた燃料経済性と排気清浄性が注目を浴びている 筒内直接噴射式火花点火成層給気機関(1)の燃焼も噴 霧燃焼の一つである，噴霧燃焼の場合，着火時はもち ろん燃焼時においても燃料の一部が依然として噴霧の 状態で混在しているため, 基本的には燃料蒸気混合気 中に噴霧が混在する場での燃焼と考えられる。そのた め燃料噴沀が混在する可燃混合気の燃焼については, 噴襍燃焼の基礎研究としてこれまでにも多くの研究が 行われている(2) - (6). 著者らも灯油噴霧とプロパン一空 気混合気を用いてこのような混合気を再現し，火花点 火特性 (7) や点火時の火炎形成過程(8) について研究を 行うとともに，一方では，燃料濃度などの火炎伝ば特 性に及ほす影響を調べた(9)，その結果，灯油噴蓩が混 在する混合気では火炎面に凹凸が生じ，場合によって

*平成 2 年 11 月 26 日 第 28 回㜣焼シンポジウムにおいて

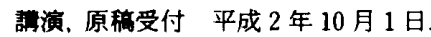

*1 正只，海上保安大学校（而737 吳市若菜町).

*2 正员，群馬大学工学部（３76 桐生市天神町 1-5-1).

*3 正只, 広島大学工学部（亚 724 東広島市鏡山 1-4-1)

*4准員, 九硝子(株)（西100 千代田区丸／内 2 丁目 1-2）
は同じ鉴度のプロパン均一混合気を上回る火炎伝ぱ速 度を示すことなどが明らかになった(9).

そこで本研究では，高速度㹡大シュリーレン映像に より，このような混合気中を伝ぱする火炎の構造を観 察し，火炎伝ぱ速度との関係について考察を加えるこ

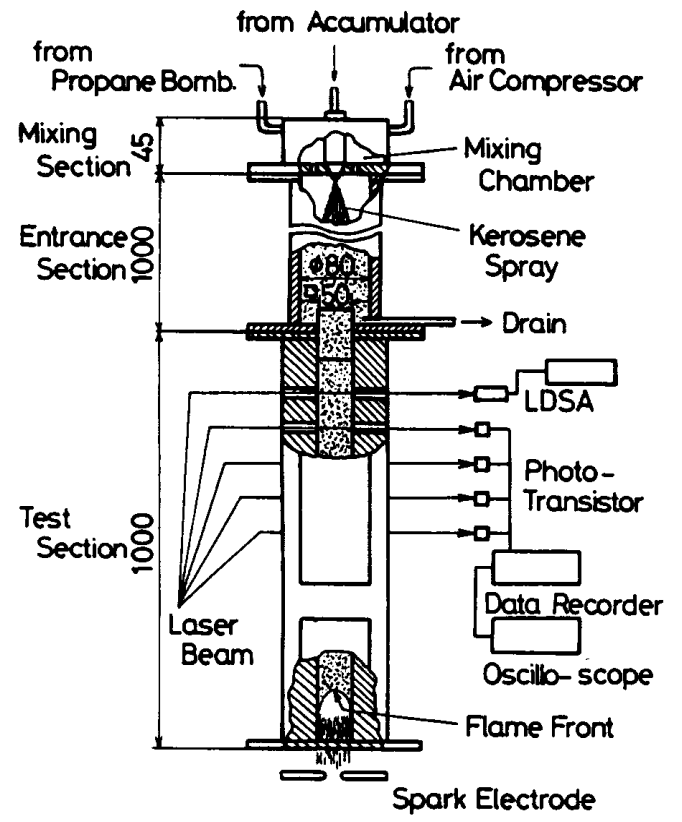

図 1 実験装置概略 
とを目的とした。また考察にあたっては，最近乱流火 炎に対して適用されているフラクタル解析 ${ }^{(10) \sim(12)}$ 用いて，火炎面の山凸の状況を定量的に表現すること をこころみた。

\section{2. 実験装置およひ実験方法}

実験装置本体は，既報(9)のものと同様である。その 概略を図 1 に示す. 頂部の混合部にはガソリン機関用 の電磁式燃料噴射弁と,プロパンおよび空気の流入口 が設けられている、混合部から噴射された灯油噴裙と プロパン混合気は，助走部で噴霧が流れにほほ一様に 分布した混合気流となり測定部に入る。測定部は全長

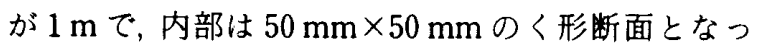
ている. 測定部の一組の側面にはアクリル製の観測突 を設け，もう 1 組の側面には光学的測定に用いる小孔 を設けた。

プロパン混合気の賑度調整は, 空気流量を $10 \mathrm{~L} /$ $\min \left\{0.01 \mathrm{~m}^{3} / \mathrm{min}\right\}$ で一定に保ち, プロパンの混入流 量を調節した。このため測定部での混合気流の平均流 速は，全実験条件を通して $0.1 \mathrm{~m} / \mathrm{s}$ 弱でほほ一定であ った。また，実験に用いた灯油噴霧のザウ夕平均粒径 は $60 \mu \mathrm{m}$ であった。

図 2 は, 高速度拡大シュリーレン撮影を行うための 光学系である.撮影は高速度ビデオ(ナック製 $\mathrm{HSV}$ -200)と,これに同期発光するストロボスコープ（菅原 製 マイクロフラッシュ 発光時間 $20 \mu \mathrm{s}$ ）を用いて, 毎秒 200 こまで行った。

シュリーレン写真法の光源とするため, ストロボス コープからの光はレンズで集光し, 直径 $3 \mathrm{~mm}$ のピン ホールを通過させたのち凹面鏡（焦点距離 $1940 \mathrm{~mm}$, 直径 $200 \mathrm{~mm}$ ) で平行光束として観測部に埒いた。観測 部を透過した光は，受光系の凹面鏡（焦点距雄 1940 $\mathrm{mm}$, 直径 $200 \mathrm{~mm}$ ）で集光される.この光束の一部を

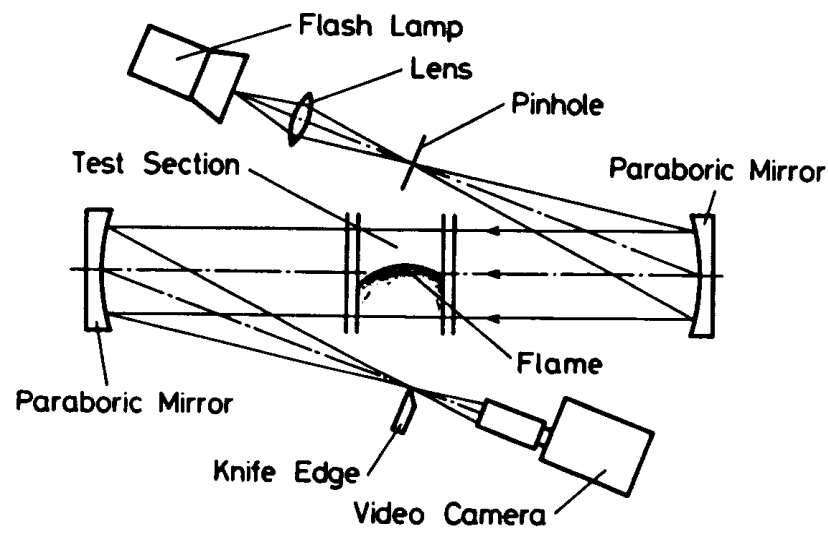

図 2 高速度桩大シェリーレン映像撮影光学系
受光系の凹面鏡の焦点位置においたナイフエッジでさ えぎり,シュリーレン像を得た。燃料噴霧液滴を抬大 してとらえるため, 高速度ビデオのレンズには, 焦点 距離 $300 \mathrm{~mm}$ のものを用いた。

また，参考のため火炎の直接像も撮影した。この場 合はナイフエッジを取り外し, 火炎の自発光による像 を $8 \mathrm{~mm}$ ビデオにより電子シャッタ $(1 / 1000 \mathrm{~s}) を$ 用い て撮影した。

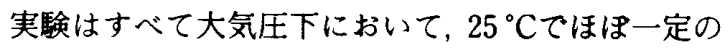

\section{Direct Photography Schlieren Photography}

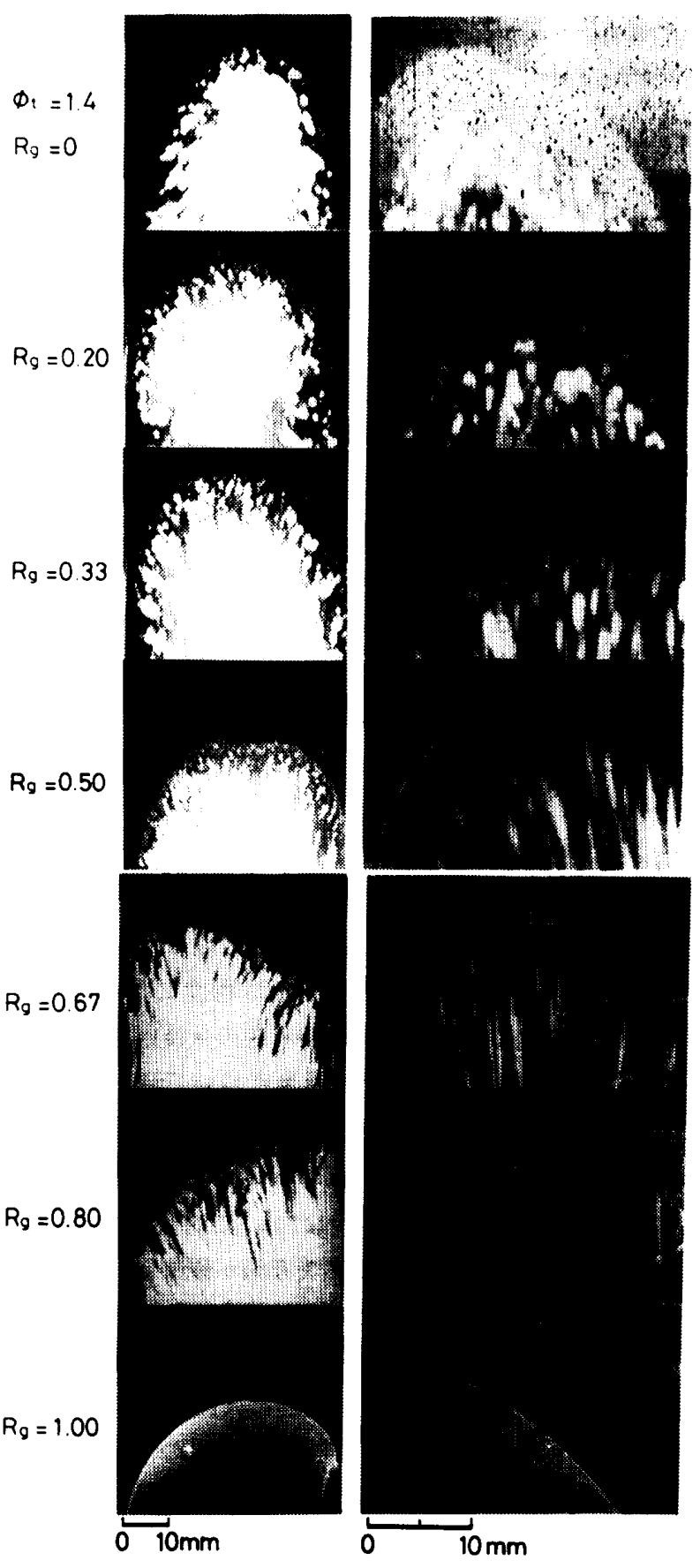

図 3 火炎伝诂状況観察結果 $\left(\phi_{t}=1.4\right)$ 
室温のもとで行った.

\section{3. 伝ぱ火炎の䊗造}

高速度拡大シュリーレン撮影結果の一例を, 図 3 に 示す。これは高速度ビデオのモニタ上の映像を, 35 $\mathrm{mm}$ スチールカメラで転写したものである，灯油噴票 とプロパンを合せた全燃料について求めた当量比（総 合当量比） $\phi_{t}$ が 1.4 の場合に，全燃料に対するプロパ ンの質量割合 (プロパン混合割合) $R_{g}$ を骞の灯油噴蓩 のみの状態から， $R_{g}=1.0$ のプロパン均一混合気の状 態まで順次変化させたときの火炎伝ぱ状況を示す，左 側は直接撮影の映像から得られた写真（直接写真）で, 右側はシュリーレン撮影の映像から得られた写真（シ ュリーレン写真) である.

プロパン混合割合 $R_{g}=0$ の灯油噴荡のみの場合, 直接写真では噴霧液滴周辺のエンベロープ火炎が密集 して,ひとかたまりの火炎を構成して燃焼しているが, その周囲にプロパン均一混合気中を火炎が伝ぱする際 にみられるような火炎面はみられない。しかし, シュ リーレン写真では, 密集して燃焼する多数のエンベロ ープ火炎の上方（火炎の進行方向）に連続した境界面 がみられる。

この境界面は, 多数のエンベロープ火炎からの熱に より前方の混合気流が加熱されることにより生じた密 度こう配によるものと考えられる，以後この境界面を 熱面と表現し，図 3 の $R_{g}=1.0$ のプロパン均一混合気 中の火炎伝ぱの直接写真にみられるようないわゆる火 炎面と区別する，熱面に流入した噴霧液滴は周囲に燃 料蒸気を形成しながら降下し，順次着火してエンべロ ープ火炎を形成する。

プロパン混合割合 $R_{g}$ を次第に増していくと, $R_{g}=$ 0.2 付近ぐらいまでは灯油噴茅のみの場合と大きな違 いはみられない. しかし， $R_{\theta}=0.33$ 程度になると，直 接写真上でところよ゙ころに薄い青色の火炎が観察され るようになり,シュリーレン写真においては熱面がは っきりとしてくる。また，プロパン混合割合 $R_{\theta}=0.2$ のときには降下する燃焼液滴からの火炎は上方に尾を 引くものしか観測されていないのに対し， $R_{\theta}=0.33$ の場合には下方に尾を引く燃焼液滴が観察される.

プロパン混合割合 $R_{g}=0.33$ の場合, 混在するプロ パン混合気の浱度 (プロパン当量比) $\phi_{\theta}$ は $0.4 \sim 0.5$ 程 度とかなり峘くなるため, 局所的に火炎面が形成され， シュリーレン写真上においても火炎面での活発な燃焼 による大きな密度こう配が熱面としてとらえられてい ると考えられる.そのためシュリーレン写真上の熱面 の輪郭も明りょうになり，また，火炎面直後の燃焼ガ
スの膨張により燃焼液滴周囲の火炎が下方に流された ものと考える。

プロパン混合割合 $R_{g}$ が 0.5 程度になると, 直接写 真で燃焼液滴群の上流に, 青色の火炎面が形成されて いるのが確認できるようになる。

さらにプロパン混合割合を增し $R_{g}=0.67 \sim 0.80$ と すると，直接写真上で火炎面がより明確になるととも に火炎面の凹凹が激しくなる，シュリーレン写真にお いては，燃焼液滴から下方に引く火炎の尾が細くかつ 長くなり，燃焼ガスの膨張がより活発であることを示 している.しかし， $R_{\theta}=1.0$ すなわちプロパン均一混 合気になると，滑らかな凹凸のほとんどない青色火炎 面となる。

プロパン混合割合 $R_{g}$ が 0.33 以下と小さい場合に は直接写真で明確な火炎面がみられず，シュリーレン 写真で観察される熱面に取り込まれた噴雺液滴が, 次々に着火して火炎伝ぱが維持される（噴霧液滴によ る火炎伝ぱ)。これに対しプロパン混合割合が 0.5 以上 と大きい場合には，火炎面が噴霧液滴を取り込みなが ら伝ぱする（予混合気による火炎伝ぱ）様子が直接写 真で観察できる。

総合当量比 $\phi_{t}$ が 1.4 以外の場合についても, 同様 の方法で火炎構造を観察したところ，やはりプロパン 混合割合 $R_{g}$ によって伝ぱ火炎の構造が変化した。し かし, 構造が変化するときのプロパン混合割合は各総 合当量比によって異なった。

図 4 は，既報(9)の実験で得られた火炎伝ぱの等速度 線図に，構造変化の遷移領域を示したものである，横

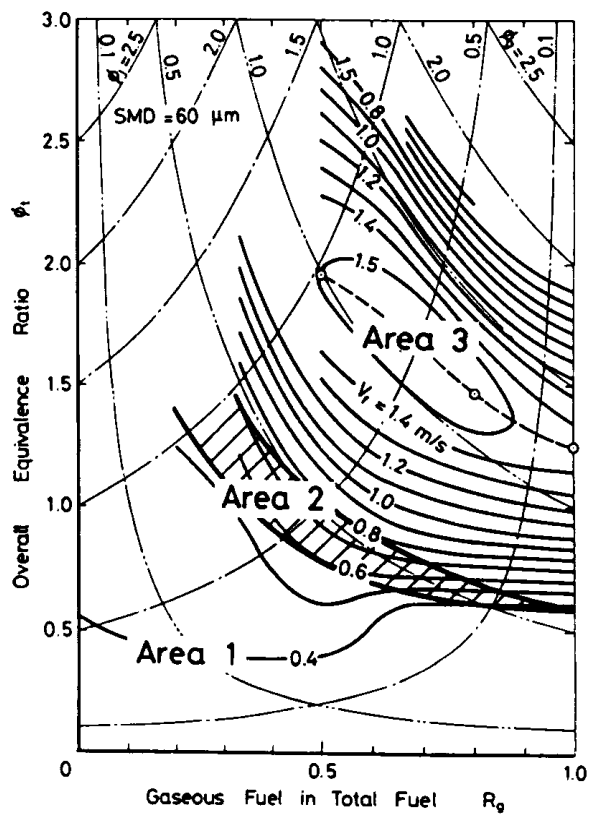

図 4 火炎伝㳊の等速度線図 
軸はプロパン混合割合 $R_{g}$ を, 綎軸は総合当量比 $\phi_{t}$ を示す. 図 4 中に領域 2 で示す斜線の部分が，伝ぱ火 炎の構造に変化が生じる遷移領域である.

図 5 は，図 4 に示す各領域での代表的な火炎構造を 示したものである. 図 4 の領域 1 では, 図 5(a)に示 す噴霧液滴による火炎伝ぱが, 領域 3 では図 5(c)に 示す予混合気による火炎伝ぱが観察された。遷移領域 2 では図 5(b) に示すように，2 種類の火炎伝ぱ形態 が混在した状況が観察された。

図 4 中に示したプロパン当量比 $\phi_{g}$ の等濃度線から もわかるように, プロパン混合気の灌度 $\phi_{g}=0.5$ 付近, すなわちプロパンの希薄可燃限界漶度 ${ }^{(13)}$ 程度となる ような場合に, 伝ぱ火炎の構造に変化が生じる。

\section{4. 考察}

図 3 に示した各条件のシュリーレン写真の熱面に対 し, フラクタル次元 $D_{\mathrm{fr}}$ を求め, 熱面の乱れの状況お よび火炎伝ぱ速度との相関について検討する，フラク タル次元 $D_{\mathrm{fr}}$ は, 最小単位長さを変化させた場合の, 測長回数の変化から求める方法(14)により得た。

図 6 に総合当量比 $\phi_{t}$ を 1.4 で一定としプロパン混 合割合 $R_{g}$ を変化させた場合の,フラクタル次元 $D_{\mathrm{fr}}$ および火炎伝ぱ速度 $V_{f}$ の変化を示した。

図6(a)をみると,フラクタル次元 $D_{\mathrm{fr}}$ は, プロパ ン混合割合 $R_{g}$ を 0 から 0.3 付近まで増加するにつれ て若干減少するが，さらにプロパン混合割合を增加す ると $R_{g}=0.4$ 付近から增加しはじめ, $R_{g}=0.8$ 付近で 最大値を示したのち減少し, $R_{g}=1.0$ のプロパン均一 混合気で最も小さな值となる。

フラクタル次元 $D_{\mathrm{fr}}$ の変化を, 図 3 のシュリーレン 写真にみられる熱面の変化状況と比較する。

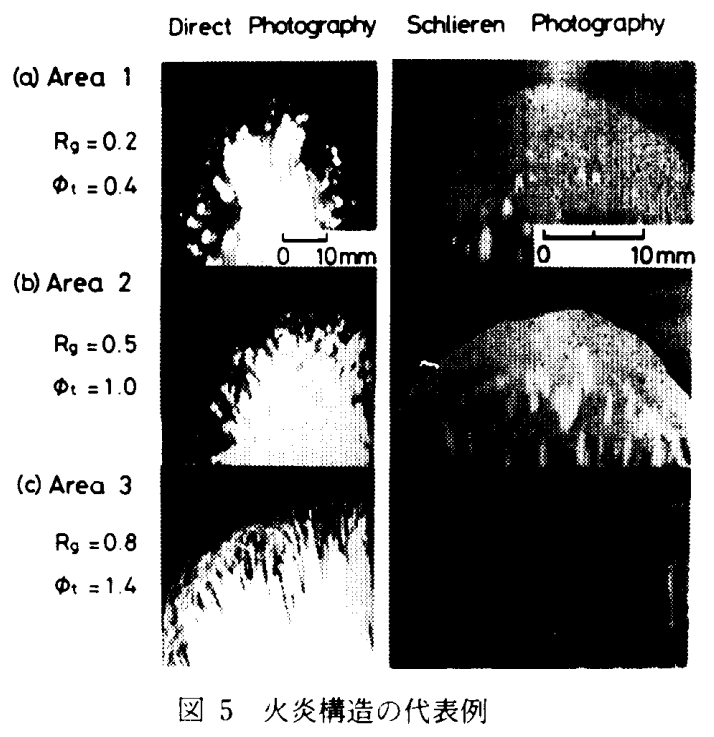

図 3 によると,プロパン混合割合 $R_{\theta}$ が $0 \sim 0.33$ の 間では，噴雺液滴の粗密の程度が凹凸となって熱面の 形状に反映されている， $R_{g}$ が 0.5〜0.8の間ではプロ パン混合割合の增加とともに火炎面の凹凸が増し $R_{g}$ $=0.8$ で最も激しくなるが, さらにプロパン混合割合 を増すと逆に凹凸が減少する。

このようにプロパン混合割合 $R_{g}$ が 0.4 程度以上で は，フラクタル次元 $D_{\mathrm{fr}}$ の増大に伴い熱面の凹凸が増 し, フラクタル次元が最も大きくなる $R_{\theta}=0.8$ 付近 で, 熱面の山凸も最も激しくなる。そしてその後, フラ クタル次元 $D_{\mathrm{tr}}$ の低下に伴い熱面の凹凸は減少し，フ ラクタル次元の最も小さい $R_{g}=1.0$ で熱面は最も滑 らかになる.すなわち, フラクタル次元 $D_{\mathrm{tr}}$ は, 熱面の 凹凸の状況を定量的に表し得るものと考える。

図 6(b)をみると，火炎伝ぱ速度 $V_{f}$ は，プロパン 混合割合 $R_{g}$ を零から 0.2 付近まで増大しても大きな 変化はみられないが, さらにプロパン混合割合を増す と $R_{g}=0.3$ 付近から増加しはじめ, $R_{g}=0.8$ 付近で最 大値を示したのち再び低下する。
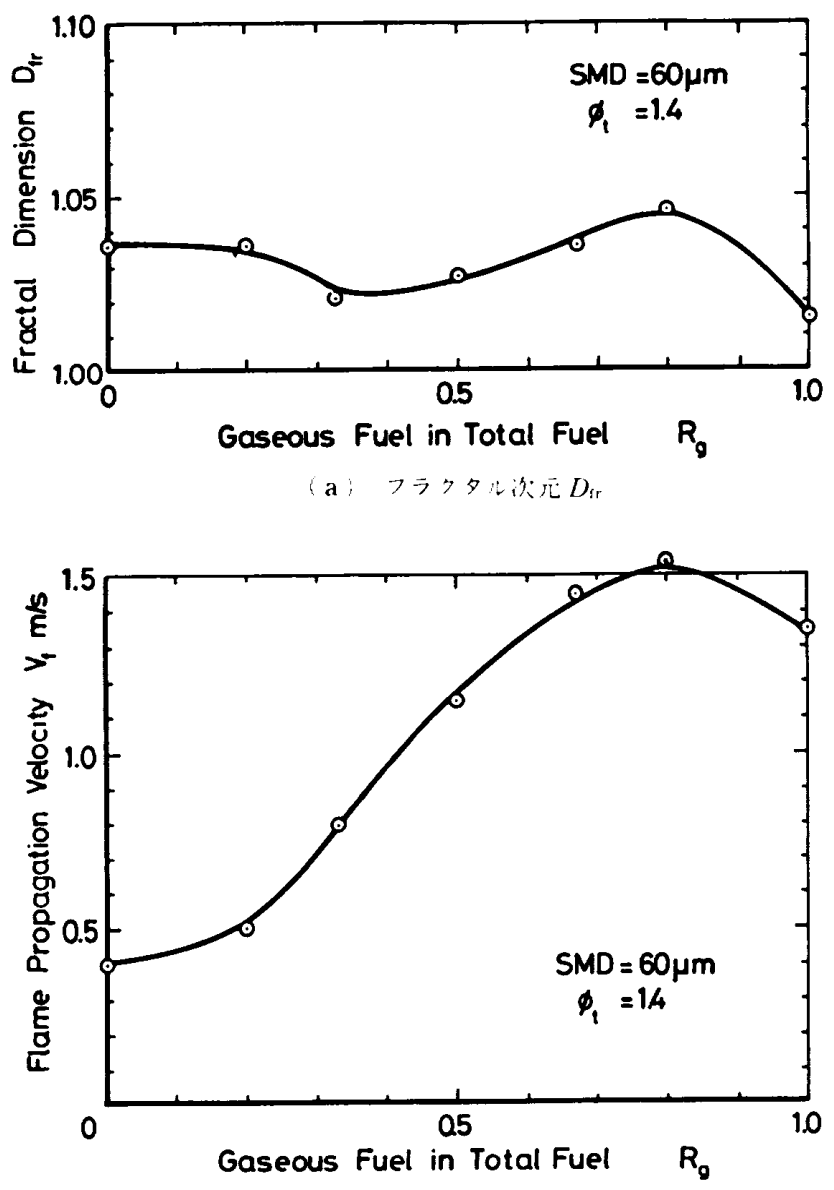

(b) 火炎怯注速度 $\mathrm{l}$ ，

図 6 フラクタル次元と火炎伝ば速度 $\left(\phi_{t}=1.4\right)$ 
この変化を, 図 6(a)のフラクタル次元 $D_{\mathrm{fr}}$ の変化 と比較する。 プロパン混合割合 $R_{g}$ の増加に伴いフラ クタル次元 $D_{\mathrm{ir}}$ が增加し最大值を示した後低下する変 化を示す $R_{\theta}$ が 0.4〜1.0の篹囲では, 火炎伝ぱ速度 $V_{f}$ も同様の変化を示し, 最大值を示すプロパン混合 割合も $R_{g}=0.8$ 程度と対応している。しかし, プロパ ン混合割合 $R_{\boldsymbol{\theta}}$ が $0 \sim 0.3$ の籍囲では, プロパン混合 割合が増すとフラクタル次元 $D_{\mathrm{fr}}$ は横ばいかまたは隇 少の傾向を示すのに対し，火炎伝ぱ速度 $V_{f}$ は増加傾 向を示す。

プロパン混合割合 $R_{g}$ が $0.3 \sim 0.4$ のとき, 混在す るプロパン当量比 $\phi_{g}$ は 0.5 程度となって火炎伝ぱ機 構の爵移域に相当し，プロパン混合割合 $R_{g}$ が 0.3 以 下では噴雼液谪に上る火炎伝ぱ, 0.4 以上では予混合 気による火炎伝ぱが燃焼を支配する. $R_{\theta}=0.3 \sim 0.4$ 付 近でフラクタル次元 $D_{\mathrm{fr}}$ が一度隇少するのは, 火炎伝 ぱ機構が変化し, 空間に散在する噴霧液滴群の局所的 な燃焼状態が緩和されることによると考えられる。す なわち, プロパン混合割合 $R_{\boldsymbol{\theta}}$ が 0.3 以下でのフラク タル次元 $D_{\mathrm{fr}}$ は，単に噴霧液滴群の分散状況できまる 熱面の形状を示しているにすぎないが、プロパン混合 割合が 0.4 以上のときのフラクタル次元は，燃焼速度 に影響を及ほす火炎面の表面積や乱れの大小に対応す るため, フラクタル次元 $D_{\mathrm{tr}}$ の変化に伴い火炎伝ば速 度 $V_{f}$ が同様の変化をするという相関がみられたと考 える。

\section{5. ま と め}

灯油噴霧-プロバンー空気混合気を用いて，燃料噴雺 が混在する可燃混合気の種々の状況を再現し,このよ うな混合気中を伝ばする火炎の構造を高速度拡大シュ リーレン映像により観察した。その結果, 次のような ことが明らかになった。

（1）火炎伝ば機構は，火炎面は観察されないが燃
料噴霧液滴が次々と着火して伝ぱを維持するもの（噴 霧液滴による火炎伝ぱ）と，予混合気中を火炎が噴䈥 液滴を取り込みながら伝ぱするもの（予混合気による 火炎伝ぱ）とに分類することができる.

（2）燃料噴霧を適度に混在させることにより火炎 面に山凸が発生し，その結果火炎面積が増大して同じ 燃料漕度のプロパン均一混合気よりも火炎伝ぱ速度が 増加する場合がある。

（3）噴雺が混在する可燃混合気においても，フラ クタル次元により火炎面の凹凸の状態を定量的に表現 することができる.

（4）火炎伝ば機構が予混合気による火炎伝ぱの場 合は, フラクタル次元と火炎伝ぱ速度の間に相関がみ られる。しかし，火炎伝ば機構が噴霧液滴による火炎 伝ぱの場合は，相関がみられない。

本実験には, 当時本学学部学生 鈴川雅也君が参加 しその協力を得た.ここに記して謝意を表する。

\section{文献}

(1) 例えば, Lewis, J. M. andTierney, W. T., SAE Paper, No. 801429(1980).

（2）水谷・中島，機論, 39-325(1973),2872.

（3）水谷・ほか 3 名, 機論, 39-325(1973)，2879.

（4）水谷・松下，機論, 39-326(1973),3160.

(5) Ballal, D. R. and Lefebvre, A. H., Proc. 18th Symp. (Int) Combust., (1981), 321.

(6) Myer, G. D. and Lefebvre, A. H., Combust. Flame, 66 (1986), 193-210.

（7）吉田・はか 2 名、機論, 56-528, B(1990)，2483.

（8）文献 ( 7)の 2490 ページ.

（9）吉田・活か3名，第 27 回燃焼シンポジウム䛱論文集， (1989), 471.

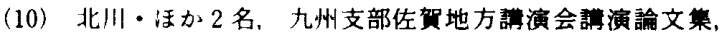
$(1990), 234$

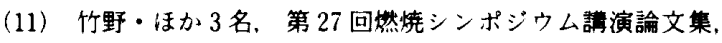
(1989), 37 .

（12）安藤・吉田, 第 27 回然焼シンポジウム諈演論文集, (1989), 389.

（13）正田・秋田，燃焼概論，(1971)，198，コロ+社

(14) 高安, フラクタル, (1986), 朝合書店, 14. 